\title{
TAZAB, HASKOBA, FREGATA: EMIGRACYJNY BIZNES W WIELKIEJ BRYTANII I WYWIAD PRL (LATA 50. I 60. XX WIEKU)
}

\author{
Krzysztof TARKA (Instytut Historii, Uniwersytet Opolski)
}

Badania dziejów polskiego wychodźstwa w Wielkiej Brytanii po II wojnie światowej koncentrują się na życiu politycznym czy dorobku kulturalnym. Takie spojrzenie jest zrozumiałe i uzasadnione, zważywszy na polityczny charakter polskiej diaspory oraz fakt, że poza krajem znalazła się znaczna część przedwojennej elity politycznej i kulturalnej. W rezultacie życie społeczne emigracji (poza pierwszymi powojennymi latami) pozostaje nadal słabo zbadanym elementem doświadczenia polskiego wychodźstwa, a działalność emigrantów na polu gospodarczym to wręcz swoista terra incognita ${ }^{1}$.

Gdy w marcu 1942 roku utworzony został Związek Kupców i Przemysłowców Polskich w Wielkiej Brytanii (Association of Polish Merchants and Industrialists) na terenie Zjednoczonego Królestwa istniały zaledwie dwa polskie przedsiębiorstwa: warsztat naprawy maszyn stolarskich i zakład produkujący wieszaki na ubrania ${ }^{2}$.

${ }^{1}$ Zob.: P. Chojnacki, Polska przedsiębiorczość nad Tamiza, [on-line]. [Dostęp: czerwiec 2014]. Dostępny w WWW: http://www.pon.uj.edu.pl/?p=4224.); R. Habielski, Życie społeczne i kulturalne emigracji, Warszawa 1999; T. Radzik, Z dziejów społeczności polskiej w Wielkiej Brytanii po drugiej wojnie światowej (1945-1990), Lublin 1991; B. Sikorski, Gospodarcze aspekty emigracji polskiej we Francji $i$ Wielkiej Brytanii, Problemy Polonii Zagranicznej 1966/1967 t. 5, s. 194-199; K. Sword, Identity in flux. The Polish community in Britain, London 1996; K. Sword, N. Davies, J. Ciechanowski, The formation of the Polish community in Great Britain 1939-1950, London 1989; J. Zubrzycki, Socjologia polskiej emigracji, Kultura $1954 \mathrm{nr}$ 7/8 (81-82), s. 118-133 i nr 9 (83), s. 77-93; J. Zubrzycki, Polish immigrants in Britain: a study of adjustment, The Hague 1956.

${ }^{2}$ S. Jóźwiak, Przedmowa, [w:] Polski informator przemystowo-handlowy, oprac. S. Konieczko, Londyn 1958, s. 5. 
W pierwszej połowie lat pięćdziesiątych na Wyspach Brytyjskich było już około tysiąca polskich przedsiębiorstw i sklepów, z czego 400 znajdowało się w Londynie ${ }^{3}$.

W strukturze emigracyjnego biznesu dominowały firmy małe, nastawione przede wszystkim na klientelę polską i zatrudniające przeważnie Polaków. W tym pionierskim okresie przeszkodą dla zakładających własne przedsiębiorstwa był nie tylko brak kapitału czy problemy z dostępem do kredytów bankowych, ale także nieznajomość języka angielskiego oraz brytyjskich przepisów prawnych i podatkowych ${ }^{4}$.

Mimo działania na obcym terenie i silnej miejscowej konkurencji polskie firmy rozwijały się dzięki pracowitości oraz wytrwałości swoich właścicieli. W końcu lat pięćdziesiątych w Wielkiej Brytanii istniało około dwóch tysięcy emigracyjnych przedsiębiorstw ${ }^{5}$. U progu następnej dekady ich liczba wzrosła do 2,5 tys. ${ }^{6}$ Według emigracyjnych szacunków w 1963 roku w Zjednoczonym Królestwie w polskich rękach znajdowało się już około 3,5 tys. przedsiębiorstw. Tak znaczna liczba firm oraz ich duża dynamika wzrostu była niewątpliwie świadectwem przedsiębiorczości Polaków, choć trzeba pamiętać, że przytoczone powyżej dane opierały się na szacunkach, które trudno zweryfikować ${ }^{7}$.

Emigracyjny biznes koncentrował się w Londynie, największym skupisku polskiej emigracji na Wyspach Brytyjskich. Polskie przedsiębiorstwa miały swoje siedziby w 150 miejscowościach, głównie na terenie Anglii (Manchester, Bradford, Nottingham, Leicester) oraz w Szkocji (Glasgow, Edynburg). Reprezentowały ogółem blisko 200 branż: od wytwórni abażurów aż do sprzedaży hurtowej i importu artykułów żywnościowych ${ }^{8}$.

Do najprężniej rozwijającej się branży należały firmy wysyłkowe (paczkowe). Na początku lat sześćdziesiątych, po podniesieniu cła na paczki przez władze PRL oraz wraz ze wzrostem bezpośrednich kontaktów między emigracją a krajem, nie był to już

${ }^{3}$ F. Zweig, Robotnik polski w Anglii, Kultura 1954 nr 3 (54), s. 94. Paweł Zaremba, rozpoczynając na łamach „Orła Białego” w 1955 roku cykl artykułów o polskim (emigracyjnym) biznesie na Wyspach Brytyjskich, stwierdził, że „firm polskich w W. Brytanii jest dużo, nawet bardzo dużo", nie pokusił się jednak o oszacowanie ich liczby; zob.: P. Zaremba, Przemyst polski w Wielkiej Brytanii, Orzeł Biały 1955 nr 20, s. 2.

${ }^{4}$ Redakcja, Trzydzieści lat działalności Związku KP $i$ WN, Wiadomości Gospodarcze 1973 nr 1, s. 3-4. Emigracyjnym biznesmenom z pomocą starał się przyjść Związek Kupców i Przemysłowców Polskich, organizując Kasę Samopomocy oraz poradnictwo prawne, podatkowe, ubezpieczeniowe czy administracyjne. Kolejnymi prezesami ZKPP byli: Stanisław Jóźwiak (1942-1959), Stanisław Gauza (1959-1961), Adam Robiński (1961-1970) i Józef Wysocki (od 1970). W 1949 roku przy ZKPP powstała sekcja Właścicieli Nieruchomości, która jeszcze w tym samym roku wchłonęła istniejący odrębnie Związek Właścicieli Nieruchomości. W 1966 roku organizacja zmieniła formalnie nazwę na Związek Kupców, Przemysłowców i Właścicieli Nieruchomości w Wielkiej Brytanii. W styczniu 1950 roku ukazał się pierwszy numer miesięcznika „Wiadomości Gospodarcze”. Pismo redagowali kolejno: W. Obtułowicz, Zbigniew Jabłkowski, F. Pawlak, a od 1962 roku Otton Hulacki; zob.: tamże.

5 S. Jóźwiak, Przedmowa, [w:] Polski informator przemystowo-handlowy, oprac. S. Konieczko, Londyn 1958, s. 5.

${ }^{6}$ Tamże, Londyn 1960, s. 5.

${ }^{7}$ A. Robiński, Przedmowa, [w:] Polski informator przemystowo-handlowy, oprac. A. Dzieduszycki, Londyn 1963, s. 7; P. Hęciak, 3500 przedsiębiorstw handlowych w polskich rękach, Orzeł Biały - Syrena 1963 nr 39, s. 2.; zob. też: R. Habielski, Życie społeczne i kulturalne emigracji, Warszawa 1999, s. 219 („Druga Wielka Emigracja 1945-1990”, t. 3).

${ }^{8}$ Polski informator przemystowo-handlowy, Londyn 1963. 
tak dochodowy biznes jak jeszcze kilka lat wcześniej. W 1963 roku tylko w Londynie wysyłką paczek za żelazną kurtynę nadal zajmowały się jednak aż 33 fírmy ${ }^{9}$.

„Przemysł paczkarski” był wymownym świadectwem łączności emigracji z krajem. Pomoc materialna udzielana przez emigrantów rodzinom w Polsce była ważną, a wydaje się niedocenianą, płaszczyzną działania powojennego wychodźstwa. W połowie lat osiemdziesiątych XX wieku emigracyjny autor Edward Chudzyński poświęcił tej sprawie nawet piosenkę:

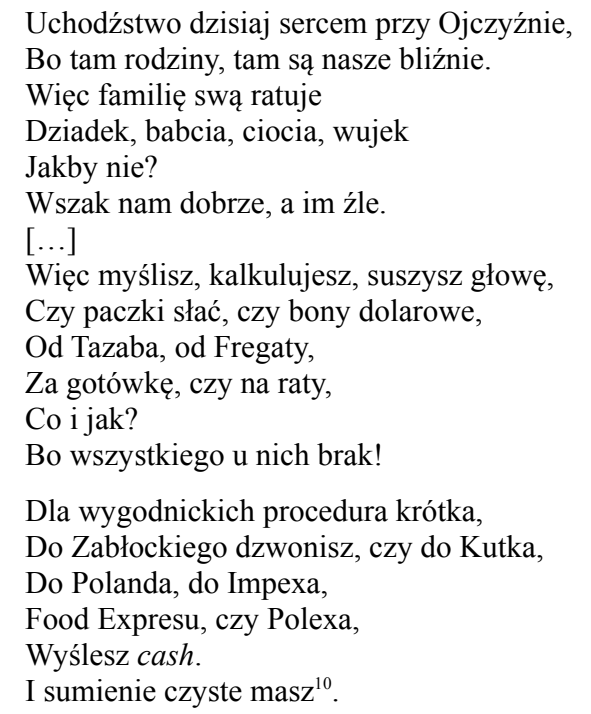

Powszechnie za największą w tej branży uważana była firma Tazab. Jej właściciel Tadeusz Zabłocki urodził się 17 listopada 1904 roku w Kijowie. Jego ojciec — Witold był kupcem i właścicielem ziemskim. Dorobił się sporego majątku, który został rozgrabiony po rewolucji bolszewickiej w Rosji. W końcu 1919 roku Zabłoccy wyjechali do Polski. W 1928 Tadeusz ukończył prawo na uniwersytecie w Poznaniu. Podczas studiów wstąpił do Młodzieży Wszechpolskiej, przez pewien czas redagował też „Głos Leszczyński”. Kolejne cztery lata pracował w Ministerstwie Spraw Zagranicznych. Doszedł do stanowiska zastępcy konsula generalnego w Amsterdamie. Dobrze zapowiadająca się kariera młodego dyplomaty została nieoczekiwanie przerwana. W 1932 roku po romansie z córką holenderskiego arystokraty, kobietą zamężną, został odwołany do kraju i zwolniony z MSZ. Od nowa rozpoczął karierę zawodową, tym razem jako adwokat w Łodzi. Po wybuchu II wojny światowej przedostał się do Francji, a następnie do Wielkiej Brytanii. Został urzędnikiem w Ministerstwie Informacji i Dokumentacji oraz publicystą londyńskiego „Dziennika Polskiego”, na łamach którego opublikował ponad 300 artykułów, felietonów i komentarzy. W 1944 roku został referentem prasowym premiera rządu RP Tomasza Arciszewskiego. Po wojnie Zabłocki pozostał na emigracji w Londynie. Zajmował się sprzedażą nieruchomości. W 1946 roku kupił

\footnotetext{
${ }^{9}$ Tamże, s. 77-78; Tamże, Londyn 1960, s. 101-110. Wymieniono tam aż 54 firmy paczkowe w Londynie i 18 na brytyjskiej prowincji.

${ }^{10}$ E. E. Chudzyński, Paczki, Dziennik Polski i Dziennik Żołnierza 1986 nr 138, s. 3.
} 
udziały w spółce założonej przez rodzinę Churchillów, handlującej meblami, antykami i luksusowymi tekstyliami ${ }^{11}$.

W lutym 1948 roku Zabłocki wraz z Kazimierzem Strumiłłą założył firmę wysyłkową Tazab and Company Limited. Kapitał zakładowy spółki wynosił 100 funtów w jednofuntowych akcjach. Siedziba firmy początkowo mieściła się przy 54 Hans Place w pobliżu Harrodsa, pod prywatnym adresem Strumiłły, który występował jako jej dyrektor. Zabłocki był formalnie doradcą i rzeczoznawcą w spółce. Już w 1949 roku dyrektorem firmy została żona Zabłockiego, Hanna, a Strumiłło od tego czasu pełnił funkcję sekretarza. Nastąpił też podział akcji. Zabłoccy przejęli po 33\% akcji, a Strumiłło 34\%. W 1954 roku akcje spółki zostały podniesione do 1000 sztuk po jednym funcie. Odtąd właścicielem 999 sztuk akcji został Zabłocki, a jedna akcja należała do jego żony ${ }^{12}$.

W okresie prosperity interesu paczkowego firma Tazab przynosiła duże zyski. W 1956 roku Zabłocki kupił czteropiętrową kamienicę przy 22 Roland Gardens (Tazab House) w londyńskiej dzielnicy Kensington, gdzie przeniósł siedzibę spółki. Firma miała filie w kilku większych skupiskach Polaków w Wielkiej Brytanii (Manchester, Birmingham, Bradford, Derby, Edynburg, Kidderminster, Nottingham, Leicester, Swindon) oraz w Stanach Zjednoczonych (Nowy Jork) czy Australii (Melbourne). W 1959 roku wspólnikiem Zabłockiego został Adam Larysz-Niedzielski, były major wojska polskiego. W tym samym roku Zabłocki kupił kolejny dom przy Old Brompton Road, a w 1961 roku dom i posesję w Surrey pod Londynem. Założył też nową spółkę - biuro podróży Tazab Travel.

Tazab reklamował się jako „największy polski dom wysyłkowy”. Firma specjalizowała się w wysyłce towarów włókienniczych i odzieży. W latach sześćdziesiątych Tazab „ubrał” niemal całą Polskę w lekkie przeciwdeszczowe płaszcze (ortaliony). Swoim klientom firma dostarczała niemal każdy towar, począwszy od lekarstw, poprzez maszyny do szycia, a na artykułach żywnościowych kończąc. Jej szef starał się, by reklamowy slogan „Od baobaba aż do kraba - możesz przesłać przez Tazaba” nie był gołosłowny. Za pośrednictwem Tazaba paczki do kraju wysyłali nie tylko Polacy, ale także Ukraińcy, Litwini, Łotysze, Rosjanie, Jugosłowianie, a nawet Włosi i Irlandczycy. Flota firmy liczyła kilkanaście samochodów dostawczych, wszystkie jednakowe: granatowe z dużym białym napisem „Tazab” na boku. Zabłocki dał pracę (i środki do życia) wielu byłym żołnierzom, dziennikarzom, artystom i politykom pozostałym na emigracji. W połowie lat pięćdziesiątych $\mathrm{w}$ jego firmie zatrudnionych było około 30 pracowników, a na początku następnej dekady już ponad 70 osób, przeważnie Polaków. Przez kilka lat magazynierem w Tazabie był generał Kordian Józef Zamorski, przed wojną komendant główny Policji Państwowej. U Zabłockiego pracował były emigracyjny minister sprawiedliwości Kazimierz Okulicz. Przez dwie dekady paczki pakował tam znany emigracyjny publicysta i pisarz Janusz Kowalewski. Ogółem w ciągu kilkudziesięciu lat przez firmy Zabłockiego (Tazab i Tazab Travel) przewinęło się ponad 150 osób.

Zabłocki stał się też jednym z największych mecenasów kultury na emigracji. Sponsorował różne emigracyjne instytucje i ludzi pióra (np. Józefa Mackiewicza). Tazab fundował doroczną nagrodę literacką tygodnika „Wiadomości”, subsydiował

${ }^{11}$ S. S. Nicieja, Z Kijowa na Piccadilly. Wokót biografii Tadeusza Zabłockiego-Gwasza, Opole 1994, s. 5-136.

12 Archiwum Instytutu Pamięci Narodowej (dalej: AIPN), 01237/144, Notatka z 30 stycznia 1963 dot. firmy Tazab i jej właściciela T. Zabłockiego. 
wydawnictwa książkowe czy polską szkołę w Mannheim. W 1990 roku Zabłocki przekazał zarząd nad firmą córkom. Sam wrócił do publicystyki. Pisał na łamach londyńskiego „Dziennika Polskiego” czy „Orła Białego”. Zmarł 13 marca 1997 roku w Londynie $^{13}$.

Władze PRL, zwłaszcza tajne służby, koncentrując się na inwigilacji i rozbijaniu emigracji, dostrzegały przede wszystkim polityczny charakter „,polskiego” Londynu, tylko w niewielkim stopniu interesowały się przy tym emigracyjnym biznesem. W końcu września 1961 roku Ministerstwo Spraw Zagranicznych zwróciło się do Ambasady PRL w Londynie o opinię w sprawie udzielenia Tazabowi przedstawicielstwa krajowego banku - Powszechnej Kasy Oszczędności (PKO). Ministerstwo Spraw Wewnętrznych o sprawie zawiadomił attaché Dionizy Biliński, „Andrzej”, w rzeczywistości oficer wywiadu cywilnego, oddelegowany na placówkę w Londynie ${ }^{14}$.

W Wydziale VIII Departamentu I MSW, zajmującym się emigracją polityczną, zapadła decyzja o przeprowadzeniu z Zabłockim rozmowy sondażowej. Miała ona wyjaśnić stosunek Zabłockiego do władz PRL oraz zorientować tajne służby, co do możliwości dofinansowywania i firmowania przez Tazab działań podejmowanych przez polską placówkę nad Tamizą. Gdyby rozmowa przyniosła wynik negatywny, „Andrzej” miał wnioskować o nieudzielanie pełnomocnictwa. W przeciwnym wypadku wywiad opowiadał się za zawarciem umowy z Tazabem, ale na jak najkrótszy okres $\mathrm{z}$ prawem przedłużenia, co w przyszłości mogło być dogodną formą nacisku na emigracyjnego biznesmena ${ }^{15}$.

Zabłockiemu bardzo zależało na uzyskaniu przedstawicielstwa PKO. W tym celu jeszcze w końcu 1961 roku do Polski jako jego przedstawiciel wyjechał E. Wencel, który na miejscu miał doprowadzić do finalizacji przedsięwzięcia. Do wywiadu dotarła informacja, że Wencel chwalił się swoimi znajomościami w sferach handlu zagranicznego. Tuż przed świętami Bożego Narodzenia Zabłocki i Wencel złożyli wizytę w Biurze Radcy Handlowego w Londynie. Zabłocki zabiegał o wystawienie pozytywnej opinii o swojej firmie. Attaché Kościński oświadczył mu, że opinię może wystawić jedynie na żądanie banku. Obecny przy rozmowie pracownik Biura, „Bąk” (w rzeczywistości oficer wywiadu), umówił się z Zabłockim na „,prywatną” rozmowę. Szef Tazaba miał w tej sprawie zatelefonować do niego po świętach. Choć od tego czasu upłynęło kilka miesięcy, nie odezwał się. Natomiast w imieniu Zabłockiego do „Bąka” kilkakrotnie dzwonił Wencel, dopytując się o wiadomości w sprawie przedstawicielstwa dla Tazaba. Wencel ponownie zjawił się w Biurze Radcy Handlowego 2 marca 1962 roku. Przekonywał „Bąka” o korzyściach, jakie przyniesie Polsce współpraca Tazaba z PKO. „Bąk” sugerował jednak, że Tazab nie otrzyma przedstawicielstwa PKO. Oświadczył, że ludzie wrogo nastawieni do władz PRL nie mogą czerpać finansowych korzyści ze współpracy z krajowymi instytucjami. Dotyczyło to firmy Tazab, której udziałowcem miał być generał Władysław Anders. „Bąk” twierdził, że firma

${ }^{13}$ Zob. szerz.: S.S. Nicieja, Z Kijowa na Piccadilly. Wokót biografii Tadeusza ZabłockiegoGwasza, Opole 1994, s. 136-196. Zob. też: B. Czaykowski, B. Sulik, Polacy w W. Brytanii, Paryż 1961, s. 317-319; J. Kowalewski, Dzieje firmy Tazab, Tygodnik Polski (Melbourne) 1977 nr 12/13, s. 6; J. Rożenek, Reportaż w „Tazabie”, Orzeł Biały 1955 nr 21, s. 2; K. Zbyszewski, Paczki od 30 lat, Dziennik Polski i Dziennik Żołnierza 1977 nr 58, s. 2; M. B. Topolska, Zabłocki Tadeusz, [w:] Encyklopedia polskiej emigracji i Polonii, red. K. Dopierała, t. 5, Toruń 2005, s. 365. Cenniki i katalogi Tazaba zob.: Biblioteka Polska w Londynie, Dokumenty życia społecznego XIV.2, Firmy wysyłkowe.

${ }^{14}$ AIPN, 01237/144, Parafraza szyfrogramu z 30 września 1961 od „Andrzeja”.

${ }^{15}$ Tamże, Parafraza szyfrogramu z 3 października 1961 do „Andrzeja”. 
Zabłockiego była politycznie powiązana z Radą Trzech i finansowała również emigracyjny „Dziennik Polski i Dziennik Żołnierza”. Wencel bezskutecznie zarzekał się, że to nieprawdziwe plotki, które rozsiewali konkurenci Tazaba. W notatce dla przełożonych oficer wywiadu dodał, że przedstawicielem Banku PKO na Wielką Brytanię ma zostać inna emigracyjna firma - Apteka Grabowskiego. Kierownictwo banku podjęło już decyzję i niebawem sprawa miała być formalnie sfinalizowana. W londyńskiej rezydenturze wywiadu nadal miano nadzieję, że Zabłocki będzie w przyszłości szukał kontaktu z „Bąkiem”. Z szefem Tazaba chciano rozmawiać, ale nie z pozycji proszącego ${ }^{16}$.

Kilka dni później Zabłocki rzeczywiście zadzwonił do „Bąka”. Umówili się na spotkanie 19 marca w restauracji Marynka. „Bąk” powtórzył swoją ,prywatną” opinię, że Tazab nie może liczyć na uzyskanie przedstawicielstwa PKO. Wskazał na polityczne podłoże sprawy, o czym już wcześniej mówił w rozmowie z Wenclem. Zabłocki przekonywał, że Anders nigdy nie miał i nie ma udziałów w jego firmie. Zgodnie z rejestrem handlowym $99 \%$ akcji należało do Zabłockiego, a 1\% do jego żony. Szef Tazaba nie zaprzeczał, że był powiązany z emigracją polską, gdyż na jej zaufaniu zbudował swój interes. Podkreślił jednak, że od początku nie angażował się w działalność polityczną. Przyznał, że wspierał finansowo wiele emigracyjnych instytucji, podobnie czynili również jego konkurenci z Haskoby czy Fregaty. Jedyną funkcją społeczną, którą sprawował było członkostwo w zarządzie Ogniska Polskiego. Chcąc zamanifestować swoją ,prokrajową" postawę, stwierdził nawet, że emigracja nie ma racji bytu, gdyż jej przywódcy nie zdołali wytworzyć żadnej atrakcyjnej koncepcji politycznej. Ze zdziwieniem mówił, że jako Polak nie może znaleźć zrozumienia w kraju, a znalazł je w Związku Sowieckim. Na dowód czego pokazał „Bąkowi” dokumenty potwierdzające, że Tazab był oficjalnym przedstawicielem sowieckiego biura podróży Inturist. O jego pozytywnym stosunku do kraju świadczyć miała deklaracja przekazania rękopisu listu Tadeusza Kościuszki do Muzeum Wojska Polskiego w Warszawie. Zabłocki powoływał się także na przyjacielskie stosunki ze Stanisławem Mackiewiczem, który kilka lat wcześniej wrócił do Polski, oraz znajomość z ministrem handlu zagranicznego - Witoldem Trąmpczyńskim. Wskazywał też na wzajemne korzyści handlowe z porozumienia między PKO i Tazabem. Na koniec dopytywał się „Bąka”, co jeszcze może zrobić, aby wykazać, że zarzuty pod jego adresem były bezpodstawne. „Andrzej”, którego „Bąk” niezwłocznie zawiadomił o rozmowie, miał nadzieję, że szef Tazaba zgodzi się „na zasadniczą rozmowę na neutralnym terenie"17. Do planowanego spotkania jednak nie doszło, gdyż Zabłocki wyraźnie nie miał ochoty wdawać się w rozmowy $\mathrm{z}$ tajnymi służbami. Emigracyjny biznesmen chciał robić handlowe interesy z krajowymi instytucjami. W zamian za uzyskanie przedstawicielstwa PKO gotów był na pewne ustępstwa, ale rola informatora komunistycznego wywiadu zdecydowanie go nie interesowała.

Mimo niepowodzenia, Zabłocki nie rezygnował z prób uzyskania przedstawicielstwa Banku PKO. 19 grudnia 1962 roku Wencel rozmawiał z „Bąkiem” w Biurze Radcy Handlowego w sprawie zakupu maszyn od Centrali Handlu Zagranicznego Centrozap. Niejako przy okazji, dopytywał się dlaczego Tazab nie może uzyskać agencji Banku PKO. Ponownie zapewniał „Bąka” o lojalności Zabłockiego wobec Polski. Twierdził, że podejrzenia wysuwane pod adresem szefa Tazaba są wymysłem jego konkurentów. Przekonywał, że Zabłocki jest człowiekiem o dużym poczuciu obowiązku i pozy-

\footnotetext{
${ }^{16}$ Tamże, Notatka z 3 marca 1962 dot. firmy Tazab oraz jej właściciela Tadeusza Zabłockiego.

${ }^{17}$ Tamże, Notatka z 19 marca 1962 dot. firmy Tazab oraz jej właściciela T. Zabłockiego.
} 
tywnym stosunku do kraju, a sprawy polityczne są mu bardzo dalekie. „Bąk” nie chciał kontynuować rozmowy w biurze i zaprosił Wencla na kawę do pobliskiej kawiarni. W odpowiedzi na wyjaśnienia i deklaracje wysłannika Zabłockiego stwierdził, że nie były one zgodne z rzeczywistością. Miał o tym świadczyć fakt, że podczas niedawnych wyborów do Rady Jedności Narodowej Zabłocki zasiadał w jednej z komisji wyborczych. Według „Bąka” w ten sposób „swoim nazwiskiem akceptował on komedię wyborów, która w swoich założeniach skierowana była przeciwko Polsce". Mimo postawionych zarzutów Wencel zapewniał, że Zabłocki wypełni wymagania stawiane mu przez władze warszawskie. O szczegółach mieli rozmawiać podczas następnego spotkania. „Bąk”, przedstawiając przełożonym plan rozmów z Tazabem, proponował, aby przed uzyskaniem przedstawicielstwa Banku PKO Zabłocki poparł na łamach emigracyjnej prasy („Dziennika Polskiego i Dziennika Żołnierza” i, „Orła Białego”) wyjazdy emigrantów do kraju oraz pochwalił osiągnięcia władz PRL na polu gospodarczym. Miał też poprzeć emigracyjny Związek Polskich Ziem Zachodnich i wziąć udział w jego pracach. Po wypełnieniu tych warunków mógłby otrzymać przedstawicielstwo Banku PKO. Gwarancją lojalności ze strony Zabłockiego miała być pisemna umowa, która w razie jego nielojalności zostałaby opublikowana w emigracyjnej prasie. „Bąk” zachęcająco dodał, że firma Tazab „przedstawia na emigracji dużą wartość i siłę i sam fakt współpracy z nami, oprócz korzyści materialnych, może przynieść nam duże korzyści polityczno-propagandowe”. Podobną opinię miał w tej sprawie „Andrzej”. Proponując Centrali przeprowadzenie zasadniczej rozmowy z Wenclem lub Zabłockim, zaznaczył:

Oczywiście trzeba by mieć w zanadrzu przyznanie przedstawicielstwa PKO. W zamian

za co Tazab - sądzimy — byłby skłonny do daleko idących „ustępstw” ${ }^{\text {"18 }}$.

Na początku lat sześćdziesiątych, po podwyżce cła na paczki przysyłane z zagranicy, drastycznie spadły obroty Tazaba. Jak ustalił „Bąk”, spadek ten miał wynieść aż $80 \%$. W rezultacie około połowy kapitału Zabłockiego (100-150 tys. funtów) miało być zamrożone w zapasach paczkowych ${ }^{19}$. Po zahamowaniu biznesu paczkowego Zabłocki szukał nowych forma działalności. Liczył, że współpraca z PKO poprawi kondycję finansową jego firmy.

W ocenie „Bąka” Zabłocki na wszelkie sposoby dążył do uzyskania przedstawicielstwa Banku PKO. Starał się pozyskać do tego celu każdego, kogo tylko mógł. Miał nawet proponować łapówki pracownikom konsulatu, aby uzyskać ich przychylność. W roku 1961 sprawa była już bliska sfinalizowania. Przebywająca w Londynie delegacja Banku PKO skłonna była podpisać z Tazabem umowę. Na przeszkodzie stanęło Biuro Radcy Handlowego. W 1962 roku przedstawiciele Zabłockiego (zwłaszcza Wencel) wielokrotnie składali wizyty w Biurze Radcy Handlowego w Londynie, gdzie przekonywali do podpisania umowy między Bankiem PKO i Tazabem. „Bąk” uważał, że ta sprawa „może przynieść nam [wywiadowi] więcej szkód aniżeli korzyści”, ${ }^{20}$. Biorąc jednak pod uwagę, że mogła ona być rozstrzygnięta z pominięciem tajnych służb, podsuwał przełożonym pomysł wykorzystania zabiegów Zabłockiego do nawiązania z nim pewnego rodzaju współpracy. Wywiad musiał się jednak dowiedzieć wcześniej niż Zabłocki o przyznaniu Tazabowi przedstawicielstwa Banku PKO. Równocześnie Zabłocki zabiegał o nawiązanie współpracy z krajowym przedsiębiorstwem Orbis.

\footnotetext{
${ }^{18}$ Tamże, Notatka z 19 grudnia 1962 dot. firmy Tazab (Zabłocki Tadeusz).

${ }^{19}$ Tamże, Notatka z grudnia 1962 dot. T. Zabłockiego.

${ }^{20}$ Tamże, Notatka z 30 stycznia 1963 dot. firmy Tazab i jej właściciela T. Zabłockiego.
} 
W tym celu w marcu 1961 roku założył spółkę Tazab Travel, która działała jako biuro podróży. $Z$ Tazabem miało być również powiązane inne emigracyjne biuro podróży Transac Services. Nawiązanie współpracy z Orbisem miało w przyszłości ułatwić Zabłockiemu zdobycie przedstawicielstwa Banku PKO. W końcu stycznia 1963 roku Zabłocki był na lunchu z Rafałem Kowalczykiem, przedstawicielem Orbisu przy konsulacie w Londynie, a w rzeczywistości oficerem wywiadu wojskowego. Rozmowę z Kowalczykiem Zabłocki dokończył w konsulacie, gdzie wcześniej nie chciał się pokazywać osobiście. Przekonywał go o korzyściach, jakie Orbis będzie miał ze współpracy z Tazabem ${ }^{21}$.

„Bąk”, zarysowując polityczną sylwetkę Zabłockiego, podkreślił, że „oficjalnie jest on czysty jak łza". Szef Tazaba nie przejawiał żadnych politycznych ambicji, koncentrując się na działalności biznesowej. W rzeczywistości należał do grona niezłomnych emigrantów gorąco popierających generała Andersa, o czym świadczył fakt, że wraz z żoną angażował się w akcję wyborczą do Rady Jedności Narodowej. W ocenie „Bąka” był też „negatywnie i wrogo nastawiony do Polski”, a w rzeczywistości do władz PRL. Poprzez fikcyjnego wspólnika Zabłockiego — Larysza-Niedzielskiego udziały w Tazabie miał mieć Anders. „Bąk” informował również przełożonych o kontaktach Zabłockiego z pracownikami attachatu wojskowego w Londynie:

Z nieznajomości całokształtu sprawy — ostrzegał - mogą oni uczynić dużo złego w całej sprawie ${ }^{22}$.

Proponował rozważenie „czy nie wskazane byłoby przestrzeżenie II Oddziału [właściwie: Zarządu II Sztabu Generalnego Wojska Polskiego] o Zabłockim lub też zwrócenie się i uzgodnienie, aby poniechali kontaktu z Tazabem i Zabłockim" 23.

„Andrzej” oczekiwał na wytyczne z Centrali dotyczące dalszego postępowania w sprawie Zabłockiego. Komentując notatkę „Bąka”, zaznaczył:

Wydaje nam się, że o ile zdecydujecie się na „interes” z Tazabem, powinno to być uczynione za duże koncesje dla nas i z solidną gwarancją ${ }^{24}$.

Decydującą rozmowę z Tazabem proponował przeprowadzić w Polsce lub na „bezpiecznym terenie". Niezadowolony z wtrącania się do sprawy wywiadu wojskowego dodał z przekąsem: „Wojskowym wypada również zwrócić uwagę, aby zanim się za coś biorą, sprawdzali w kartotekach",25.

Gdy po kilku latach bezskutecznych starań Zabłocki otrzymał wreszcie obywatelstwo brytyjskie, po raz pierwszy po latach przyjechał do Polski. Po powrocie do Londynu w połowie 1963 roku rozpowiadał, że podczas pobytu w kraju funkcjonariusze Służby Bezpieczeństwa (zapewne wywiadu cywilnego) nakłaniali go do podjęcia tajnej współpracy, na którą zdecydowanie się nie zgodził. Z tego powodu fiaskiem zakończyły się jego plany współpracy z PKO. Na tej podstawie Zabłocki wyciągał wniosek, że

21 Tamże.

22 Tamże.

23 O krążących w ,polskim” Londynie plotkach o finansowym powiązaniu Zabłockiego i Andersa donosił Karol Lewkowicz, redaktor naczelny „prokrajowego” pisma „Oblicze Tygodnia” i tajny współpracownik wywiadu cywilnego o ps. „Heliotrop”; zob.: AIPN, 01237/144, Notatka [b.d.] dot. Tadeusza Zabłockiego, właściciela firmy Tazab (źródło: „Heliotrop”).

${ }^{24}$ AIPN, 01237/144, Odręczny dopisek „Andrzeja” z 1 lutego 1963 na notatce dot. firmy Tazab i jej właściciela T. Zabłockiego z 30 stycznia 1963.

${ }^{25}$ Tamże. 
emigracyjne firmy, mające przedstawicielstwo Banku PKO, muszą współpracować z komunistycznymi tajnymi służbami ${ }^{26}$.

Wywiad od dawna uważał Zabłockiego za człowieka Andersa. W przekonaniu tajnych służb szef Tazaba utrzymywał kontakt z peerelowskimi placówkami nad Tamizą (ambasadą i konsulatem generalnym) za zgodą generała. Każdorazowo miał go też informować o pobycie w Polsce. Zabłocki rzekomo zawiadomił również Andersa, że podczas jednej z wizyt w Warszawie do jego pokoju w hotelu „Bristol” przyszło dwóch mężczyzn, by zaproponować mu współpracę ${ }^{27}$. Ostatecznie próby werbunku nie przyniosły jednak powodzenia.

Najpoważniejszym konkurentem Tazaba na emigracyjnym rynku była firma wysyłkowa Antoniego Cassel-Kokczyńskiego - Haskoba, reklamująca się jako „największy polski dom wysyłkowy w Europie”. Siedziba firmy mieściła się w „,polskim korytarzu” w Londynie przy 121 Earl's Court Road. Haskoba była najstarszą polską firmą wysyłkową w Wielkiej Brytanii. Jej dewizą był slogan: „Dobra i szybka pomoc to paczka Haskoby". W połowie lat pięćdziesiątych w biurach i magazynach firmy w Londynie pracowało 20 osób. Haskoba miała również kilkudziesięciu agentów w Kanadzie, Stanach Zjednoczonych, Południowej Afryce, Australii, Nowej Zelandii, Argentynie i Brazylii. Tygodniowo wysyłała przeciętnie tysiąc paczek do Polski i za „linię Curzona”, do Związku Sowieckiego, głównie z artykułami włókienniczymi i lekarstwami $^{28}$.

Antoni Kokczyński urodził się 4 stycznia 1910 roku w Dorpacie, w dawnych Inflantach (obecnie Tartu w Estonii). Jego ojciec Feliks był notariuszem. Wiedza tajnych służb na temat działalności dyrektora Haskoby przed II wojną światową była bardzo niewielka. Na podstawie szczątkowych informacji wiedziano, że był urzędnikiem w Ministerstwie Spraw Zagranicznych. Wojnę spędził na Dalekim Wschodzie, gdzie przebywał w dość trudnych warunkach materialnych. Po wojnie osiedlił się w Wielkiej Brytanii i uzyskał obywatelstwo brytyjskie. Krótko pracował w emigracyjnym MSZ, a następnie zajął się działalnością gospodarczą ${ }^{29}$. W końcu lat trzydziestych Kokczyński rzeczywiście był referentem w MSZ. We wrześniu 1939 roku, jako żołnierz 20. pułku ułanów, dostał się do niewoli sowieckiej, skąd uciekł. Niebawem został jednak aresztowany przez NKWD na granicy węgierskiej. Więziony w Stanisławowie, Chersoniu, Nikołajewie i Tomsku wolność odzyskał na podstawie umowy Sikorski-Majski we wrześniu 1941 roku. Przez pół roku (do połowy kwietnia 1942 roku) był sekretarzem Delegatury Ambasady RP w Taszkiencie i Samarkandzie, a następnie urzędnikiem w Ambasadzie RP w Kujbyszewie. W końcu grudnia 1942 roku został attaché, a następnie chargé d'affaires Ambasady w Czungkingu. W chińskiej placówce pozostał do marca 1943 roku. Po powrocie do Londynu czasowo przydzielono go do Ministerstwa Przemysłu i Handlu, a od początku 1945 roku był kierownikiem referatu Stanów Zjednoczonych w Wydziale Amerykańskim MSZ. W centrali MSZ w Londynie praco-

\footnotetext{
${ }^{26}$ Tamże, Raport z rozmowy z „Kędzikiem” [Jerzy Z. Kędzierski] odbytej w dniu 21 sierpnia 1963.

${ }^{27}$ AIPN, 01168/397, Notatka z 16 lutego 1966 dot. Andersa i jego organizacji; Zob. też: „,Wybitnie wroga jednostka”. Komuniści przeciwko generałowi Władysławowi Andersowi 19431970. Wybór dokumentów, wybór i oprac. B. Polak, M. Polak, Leszno 2008, s. 118.

28 J. P. Herwarth, Reportaż w „Haskobie”, Orzeł Biały 1955 nr 22, s. 2; Rocznik Polonii 1958-59, s. 229. Cenniki i katalogi Haskoby; zob.: Biblioteka Polska w Londynie, Dokumenty życia społecznego, XIV.2, Firmy wysyłkowe.

${ }^{29}$ AIPN, 01227/172, Notatka informacyjna z 22 kwietnia 1959 dot. Cassel-Kokczyński Antoni krypt. „Kask”.
} 
wał do wycofania uznania rządowi RP przez Stany Zjednoczone i Wielką Brytanię na początku lipca 1945 roku. Następnie zajął się działalnością gospodarczą. W listopadzie 1945 roku został dyrektorem spółki Haskoba ${ }^{30}$.

Sytuacja materialna Kokczyńskiego zdecydowanie poprawiła się po zawarciu małżeństwa z Dianą Cassel, córką admirała szwedzkiego. Nazwisko panieńskie żony Kokczyński dołączył do swojego i używał ich odtąd obydwu łącznie. W 1958 roku CasselKokczyński wykupił akcje biura podróży Stanmore. Był też właścicielem kilku domów w Londynie, a po teściu odziedziczył plantację ryżu w Maroku. Emigracyjny biznesmen utrzymywał kontakt listowy ze swoim bratem Stanisławem, mieszkającym w Warszawie. Pomagał również materialnie jego rodzinie, przesyłając paczki z różnymi atrakcyjnymi artykułami. Żona Stanisława w 1957 roku przez trzy miesiące przebywała w Londynie, zaś jego syn w końcu tego roku przyjechał na studia. W kraju mieszkały jeszcze dwie siostry „Kaska” (pseudonim nadany Cassel-Kokczyńskiemu przez wywiad), z którymi nie utrzymywał on jednak bliższych kontaktów ${ }^{31}$.

W końcu stycznia 1957 roku Cassel-Kokczyński jako obywatel brytyjski przyjechał do Warszawy w odwiedziny do brata. Znalazł się wówczas w operacyjnym zainteresowaniu wywiadu cywilnego PRL. Jednak ze względu na brak możliwości dotarcia do „Kaska” tajne służby nie przeprowadziły żadnych przedsięwzięć operacyjnych. Jeszcze przed wyjazdem do Polski Cassel-Kokczyński, składając wniosek o udzielenie wizy, wdał się w pogawędkę z urzędnikiem Konsulatu Generalnego PRL w Londynie Mirosławem Opilskim „Nowackim”, w rzeczywistości funkcjonariuszem londyńskiej rezydentury wywiadu. W trakcie rozmowy powiedział, że jest właścicielem firmy Haskoba, zatrudniającej blisko czterdzieści osób, przeważnie polskich emigrantów. Podczas pobytu w kraju Cassel-Kokczyński zamierzał przeprowadzić rozmowy na temat ewentualnego otwarcia filii Haskoby w Warszawie. Kurtuazyjnie zaprosił też „Nowackiego", aby odwiedził go w jego firmie. Pod pretekstem zakupów oficer wywiadu zamierzał zorientować się w możliwościach ewentualnego rozpracowania „Kaska” i wykorzystania go „dla naszych celów”,32.

W Warszawie Cassel-Kokczyński prowadził rozmowy z Polską Izbą Handlu Zagranicznego w sprawie otwarcia filii swojej firmy. Zabiegał również o uzyskanie przedstawicielstwa Banku PKO. Gdy wrócił do Londynu, kilka razy rozmawiał z nim „Nowacki”, który podczas jednej z wizyt w Haskobie zapoznał go z Edwardem Jankiewiczem — „Grabskim”, oficjalnie drugim sekretarzem w Ambasadzie PRL w Londynie, faktycznie rezydentem wywiadu. Próba nawiązania współpracy z „Kaskiem” nie przyniosła jednak rezultatu. Dyrektor Haskoby nie był zainteresowany utrzymywaniem kontaktu z „Nowackim”. Jeszcze wyraźniej unikał kontaktu z „Grabskim” czy peerelowską placówką nad Tamizą.

Potencjalnie Cassel-Kokczyński jako człowiek inteligentny, dobrze sytuowany, tkwiący w ciekawym środowisku, często podróżujący do różnych krajów, mógł być dla komunistycznych tajnych służb cennym informatorem czy agentem wpływu. Dzięki

${ }^{30}$ Polska służba zagraniczna po 1 września 1939 r., Londyn 1954, s. 33 i 106; Z. Czeczot-Gawrak, Powroty do MSZ, [w:] Przed Wrześniem i po Wrześniu. Ze wspomnień młodych dyplomatów II Rzeczypospolitej, Warszawa 1998, s. 145.

${ }^{31}$ AIPN, 01227/172, Notatka informacyjna z 22 kwietnia 1959 dot. Cassel-Kokczyński Antoni krypt. „Kask”. W latach 60. Cassel-Kokczyński stworzył prywatną galerię malarstwa Cassel Gallery; zob.: Biblioteka Polska w Londynie, Dokumenty życia społecznego, IX.1.8, Cassel Gallery.

${ }^{32}$ Tamże, Informacja z 24 stycznia 1957 dot. Cassel-Kokczyński Antoni Hubert — dyrektor firmy Haskoba Ltd. 
swojej pozycji finansowej oraz znajomościom żony utrzymywał bliskie kontakty z angielskimi arystokratami czy posłami do parlamentu. Osobiście znał też wielu działaczy emigracyjnych. W jego domu często bywał generał Władysław Anders. Z informacji, które docierały do wywiadu wynikało, że „Kask” był jednak zdecydowanie negatywnie nastawiony do władz PRL. W końcu 1958 roku, podczas rozmów z delegacją Orbisu przebywającą w Londynie, wspominał o wywózkach Polaków na Sybir, władze w Warszawie nazywał „reżymem”, a pracowników Ambasady PRL w Londynie „reżymowcami”. Wiosną 1959 roku Cassel-Kokczyński planował ponownie przyjechać do kraju. W Warszawie miał rozmawiać z przedstawicielami Orbisu na temat organizowania wycieczek turystycznych z Wielkiej Brytanii do Polski. Wywiad planował wykorzystać jego wizytę do dalszego „opracowania” go i ewentualnego werbunku ${ }^{33}$.

19 maja 1959 roku porucznik Zbigniew Ślusarski, oficer operacyjny wywiadu, rozpatrzywszy materiały dotyczące „Kaska”, przygotował postanowienie o założeniu sprawy agenturalnej ${ }^{34}$. Już dwa lata później kapitan Ślusarski musiał jednak przyznać się do porażki wywiadu. W postanowieniu o zakończeniu sprawy stwierdził, że CasselKokczyński ,jako kandydat na werbunek nie rokuje nadziei, gdyż nie ma perspektyw zwerbowania go"35.

Antoni Cassel-Kokczyński zmarł 5 stycznia 1995 r. w Londynie ${ }^{36}$.

Liberalizacja systemu komunistycznego w Polsce i zmiana taktyki władz PRL wobec wychodźstwa w połowie lat pięćdziesiątych przyczyniły się do ożywienia bezpośrednich kontaktów między emigracją a krajem. Wyraźnie wzrosła liczba Polaków wypuszczanych na Zachód, coraz więcej emigrantów odwiedzało też dawno niewidzianą ojczyznę, a niektórzy wracali do Polski na stałe (wizyty w kraju rządzonym przez komunistów władze emigracyjne nadal uważały jednak za sprzeczne z etosem emigranta politycznego). Załatwianiem wszelkich spraw związanych z wyjazdami do kraju czy sprowadzaniem rodzin (zakup biletów kolejowych, morskich czy lotniczych, rezerwacja hoteli, transfer pieniędzy i zakup obcych walut, ubezpieczenia od wypadków i bagażu) zajmowały się powstające na emigracji biura podróży. Według Polskiego informatora przemystowo-handlowego z 1958 roku w Londynie działały zaledwie cztery polskie biura podróży. Dwa lata później było ich już siedem, a w 1963 roku takich firm było aż 13, co świadczy o wzroście zapotrzebowania na tego rodzaju usługi. Do największych należała Fregata Travel Ltd. Tadeusza Kutka. Siedziba firmy mieściła się w centrum Londynu przy 122 Wardour Street ${ }^{37}$.

Tadeusz Kutek urodził się 10 października 1917 roku we wsi Perła koło Tarnowa. W 1935 roku zdał maturę w prowadzonym przez jezuitów gimnazjum w Chyrowie i wstąpił do Wyższej Szkoły Marynarki Wojennej na Oksywiu. Trzy lata później został skierowany na kurs artylerii morskiej do Wielkiej Brytanii. Pływał na okrętach Royal „Kask”.

${ }^{33}$ Tamże, Notatka informacyjna z 22 kwietnia 1959 dot. Cassel-Kokczyński Antoni krypt.

${ }^{34}$ Tamże, Postanowienie z 19 maja 1959 o założeniu sprawy agenturalnej kryptonim „Kask”.

${ }^{35}$ Tamże, Postanowienie z 26 sierpnia 1961 o zakończeniu i przekazaniu sprawy kryptonim „Kask” do archiwum.

${ }^{36}$ Nekrologi A. Cassel-Kokczyńskiego zob.: Dziennik Polski i Dziennik Żołnierza $1995 \mathrm{nr}$ 9, s. 7

${ }^{37}$ Polski informator przemystowo-handlowy, Londyn 1958, s. 110; Polski informator przemystowo-handlowy, Londyn 1960, s. 118-121; Polski informator przemystowo-handlowy, Londyn 1963 , s. 80-82. 
Navy. Wybuch II wojny światowej zastał go na południowym Atlantyku. W latach 1939-1940 Kutek służył na niszczycielu ORP „Grom”. 4 maja 1940 roku okręt został zatopiony przez niemieckie lotnictwo w jednym z norweskich fiordów. Kutka uratowali wówczas Anglicy. Kilka miesięcy później brytyjski Zarząd Operacji Specjalnych (SOE) wysłał go na teren okupowanej Europy. Kutek został jednak aresztowany przez Niemców i jesienią 1941 roku trafił do obozu koncentracyjnego w Dachau, skąd uciekł w lutym 1945 roku. Przedostał się do Francji, a następnie do Wielkiej Brytanii. Ponieważ doskonale znał język niemiecki, brał udział w pracach brytyjskiej komisji przesłuchującej oficerów Kriegsmarine. Po zakończeniu wojny pozostał na emigracji. Do 1949 roku pływał na brytyjskich okrętach jako pierwszy oficer. Odbył kilka rejsów ze wschodniej Afryki do Argentyny z polskimi emigrantami. Pływał także po Oceanie Indyjskim, Pacyfiku i Morzu Chińskim z transportami wojsk brytyjskich oraz zaopatrzeniem. W 1948 roku brał udział jako thumacz w przekazaniu Hajfy Izraelowi (znał biegle sześć języków). Za zasługi dla brytyjskiej marynarki w 1949 roku został mianowany dyrektorem do spraw nauki, a następnie kapitanem okrętu szkolnego dla kandydatów na oficerów marynarki handlowej. W 1955 roku na własną prośbę odszedł ze służby w marynarce brytyjskiej i odkupił od dotychczasowych właścicieli biuro podróży Fregata Travel. Korzystając ze swoich kontaktów, doprowadził do rozmów przedstawicieli władz brytyjskich i polskich (krajowych) w sprawie otwarcia regularnych połączeń lotniczych między obydwoma krajami. 1 kwietnia 1958 roku uczestniczył w inauguracyjnym locie z Londynu do Warszawy. Został pierwszym oficjalnym przedstawicielem Polskich Linii Lotniczych LOT w Wielkiej Brytanii. Uruchomił też ruch czarterowy z Londynu i Manchesteru do Warszawy i Krakowa. W latach sześćdziesiątych zorganizował stałe połączenie kolejowe Londyn-Poznań, a od połowy lat siedemdziesiątych linię autobusową. Swoje doświadczenie przeniósł na grunt amerykański, gdzie w 1959 roku był współzałożycielem Stowarzyszenia Polsko-Amerykańskich Biur Podróży. Na przełomie lat siedemdziesiątych i osiemdziesiątych zaaranżował pierwsze kontakty między LOT a zakładami Boeinga w Seattle. W 1981 roku wygrał konkurs na dyrektora generalnego PLL LOT, stanowiska jednak nie objął. W połowie lat dziewięćdziesiątych osiadł na stałe w Chicago. Na antenie polonijnego radia wygłaszał cykliczne pogadanki o tematyce historycznej. W 2002 roku został odznaczony Krzyżem Kawalerskim Orderu Zasługi Rzeczypospolitej Polskiej. Zmarł 7 czerwca 2003 roku w Chicago ${ }^{38}$.

Spółka Fregata Limited była firmą z przedwojenną tradycją. Założyli ją w 1936 roku we Lwowie młodzi absolwenci Wyższej Szkoły Handlu Zagranicznego. W marcu 1947 roku kilku „fregatowców” reaktywowało firmę w Londynie. W pierwszych latach na emigracji spółka koncentrowała się na działalności usługowej, zajmując się pośrednictwem pracy, wysyłką paczek czy sprzedażą domów. Kilka lat później powstały dwie spółki córki: Fregata Marchants (obejmująca firmę importową oraz sieć sklepów spożywczych w Londynie) oraz Fregata Travel (biuro podróży) ${ }^{39}$.

${ }^{38}$ R. Cuber, Wielki Kapitan z małej Perly, Brzeski Magazyn Informacyjny 2003 nr 9, s. 1617; J. Jaworski, Kutek Tadeusz, [w:] Encyklopedia polskiej emigracji i Polonii, red. K. Dopierała, t. 3, Toruń 2005, s. 100; T. Kutek, Syzyfowe prace: Polskie Linie Lotnicze „LOT” i moich czterdzieści kilka lat niespetnionych dążé, Chicago 1999. W latach 70. Fregata Travel wykonywała w sezonie letnim około 100 lotów czarterowych z Wielkiej Brytanii do Polski oraz 30-40 lotów w sezonie zimowym. Drugim kontrahentem PLL LOT był Tazab, ale rozmiary współpracy z firmą Zabłockiego były niewielkie; zob.: Wspótpraca gospodarcza Polski z Polonia brytyjska, oprac. W. Kudła, Warszawa 1980, s. 90.

${ }^{39}$ P. Heciak, Zwiąek firm handlowych, Orzeł Biały 1955 nr 27, s. 2. 
Gdy w 1955 roku Kutek wykupił akcje Fregaty Travel, wywiad cywilny PRL podejrzewał, że był on tylko figurantem firmującym transakcję. Rzeczywistym właścicielem znacznej części akcji Fregaty miał być generał Anders. Tajne służby zainteresowały się spółką w 1956 roku, gdy Kutek zjawił się w Konsulacie Generalnym w Londynie. Dyrektor Fregaty zabiegał wówczas o uzyskanie przedstawicielstwa krajowego biura podróży Orbis. W następnym roku Kutek po raz pierwszy wyjechał do Polski w celu sfinalizowania umowy. Od tej pory często przyjeżdżał do kraju. Jego żona i dzieci spędzały z reguły wakacje w Polsce, gdzie mieszkała matka i siostra Kutka (ojciec zmarł w 1960 roku). Uzyskanie przedstawicielstwa Orbisu przyczyniło się do szybkiego rozwoju Fregaty, która z niewielkiej firmy zatrudniającej początkowo trzy osoby przekształciła się w duże biuro podróży zatrudniające w końcu lat pięćdziesiątych ponad 30 osób. Sam Kutek niemal zmonopolizował miejscowy rynek, zwłaszcza gdy Konsulat Generalny PRL otrzymał polecenie kierowania interesantów do Fregaty jako przedstawiciela Orbisu. $Z$ tego tytułu przez kilka lat dyrektor Fregaty czerpał znaczne korzyści finansowe. Sprzyjał mu wzrost wyjazdów emigrantów do kraju oraz uzyskanie przedstawicielstwa Orbisu i Banku PKO. Do polskiej placówki nad Tamizą (oraz rezydentury wywiadu) docierały jednak coraz częściej informacje o nadużyciach dewizowych i zawyżaniu przez Kutka cen niektórych wycieczek do kraju ${ }^{40}$.

W 1961 roku ujawnione zostało wysokie zadłużenie Fregaty wobec Orbisu, sięgające aż 20 tysięcy funtów. Podczas pobytu w kraju Kutek był nawet dwukrotnie przesłuchiwany w tej sprawie w Komendzie Wojewódzkiej Milicji Obywatelskiej i przez prokuratora. Dyrektor Fregaty odpowiedzialność zrzucał na Orbis, skarżąc się, że nie otrzymał na czas rozliczeń. W rzeczywistości do powstania tak dużego zadłużenia miała się przyczynić namiętność Kutka do hazardu (poker), utrzymywanie deficytowej filii Fregaty w USA, zatrudnienie zbyt dużej liczby osób w londyńskiej centrali spółki oraz pomoc finansowa dla „Dziennika Polskiego i Dziennika Żołnierza”. Orbis uratował Fregatę przed bankructwem, rozkładając zadłużenie na bardzo dogodne raty oraz przedłużając przedstawicielstwo. Postępowanie Orbisu zaskoczyło pracowników konsulatu i Biura Rady Handlowego w Londynie. Poparcie Kutek miał zdobyć drogimi prezentami dla pracowników Orbisu (mówiono o złotych zegarkach). W ocenie wywiadu PRL:

Kutek nie jest poważnym i uczciwym partnerem handlowym, a kontynuowanie $\mathrm{z}$ nim umowy - wbrew zdrowemu rozsądkowi — wskazuje, że istotnie musi on posiadać w kraju b[ardzo] wpływowych protektorów ${ }^{41}$.

Ruchliwy i rzutki biznesmen szukał różnych źródeł zarobku. Do wywiadu PRL dotarły pogłoski, że Kutek był pośrednikiem pomiędzy LOT-em a koncernem lotniczym Viscount. Na początku 1961 roku przyjechał też do Polski jako przedstawiciel na Europę Wschodnią brytyjskich firm samochodowych Jaguar i Rover. Dwa lata później Kutek miał być źródłem przecieku do emigracyjnej prasy na temat zakupu najnowszego modelu Jaguara przez premiera PRL Józefa Cyrankiewicza. Od krajowej agentury pochodziła wiadomość, że Cyrankiewicz zaprosił Kutka na przyjęcie w pałacyku Rady Ministrów w Natolinie. Dyrektor Fregaty bowiem chwalił się przejażdżką nowym Jaguarem $\mathrm{z}$ premierem PRL.

Właściciel Fregaty nie prowadził działalności politycznej. Nie należał też na emigracji do żadnego ugrupowania. Podkreślał, że był jedynie członkiem Polskiego Klubu

\footnotetext{
${ }^{40}$ AIPN, 01136/102, Notatka z 12 listopada 1963 dot. A. Kutka.

${ }^{41}$ Tamże.
} 
Motorowego w Londynie. Jednak w ocenie wywiadu Kutek tylko kreował się na „lojalnego handlowca" i pioniera poprawnych stosunków emigracja-kraj. W rzeczywistości miał być zwolennikiem „niezłomnych” i popierał Andersa. Miał się nawet przechwalać, że generał prosił go o pomoc finansową dla londyńskiego „Dziennika Polskiego". Powodzenie w interesach rzekomo było źródłem ambicji politycznych Kutka, który chciał być poważany w tej dziedzinie. W towarzyskich rozmowach twierdził, że jest nie tylko handlowcem, ale także osobą, która będzie miała dużo do powiedzenia w sferze politycznej. W 1959 roku, w szczytowym okresie powodzenia Fregaty, Kutek miał twierdzić w rozmowie ze znajomym, a ten doniósł o tym wywiadowi, że „trzeba robić wszystko, aby na komunistach zarabiać jak najwięcej, z drugiej zaś strony trzeba ich zwalczać, gdzie się tylko da. Mogą to robić ludzie tak inteligentni jak ja, który w oczach Orbisu i Ambasady uchodzi za przyjaciela Polski’"42.

W tym czasie Kutek nosił się z zamiarem wydawania własnego pisma. W tej sprawie prowadził nawet zaawansowane rozmowy z działaczami Polskiego Ruchu Wolnościowego Niepodległość i Demokracja. Jesienią 1958 roku, podczas pobytu w kraju, zabiegał w Ministerstwie Spraw Zagranicznych o uzyskanie serwisu krajowego PAP i serwisu fotograficznego CAF. Wcześniej na ten temat rozmawiał z dyrektorem Polskiej Agencji Prasowej. Nowy emigracyjny tygodnik ilustrowany miał być finansowany przez prywatnych sponsorów. Na redaktora naczelnego przewidywano Bolesława Świderskiego, właściciela księgarni w Domu Kombatanta w Londynie. Pismo miało mieć objętość dwunastu stron i nakład 15 tysięcy egzemplarzy, a redakcja opowiadać się za zacieśnieniem stosunków między emigracją a krajem. Gdy przygotowania do wydania pierwszego numeru były już zaawansowane, Kutek nieoczekiwanie wycofał się z tego pomysłu. W rezultacie projekt nie został zrealizowany. Pojawiły się nawet pogłoski, że Kutek w tym wypadku działał z polecenia Andersa jako prowokator, który miał skłócić opozycję w Tymczasowej Radzie Jedności Narodowej i rozpoznać jej zamiary ${ }^{43}$.

Dyrektor Fregaty często miał się też przechwalać, że w Polsce jest w stanie wszystko załatwić, gdyż ma w kieszeni wielu działaczy komunistycznych oraz wyższych urzędników ministerialnych. Wywiad przyznał, iż nie były to tylko czcze przechwałki, a Kutek rzeczywiście miał w kraju poparcie osób wpływowych, choć nigdy nie wymienił ich nazwisk. Miał o tym świadczyć fakt, że gdy w sierpniu 1960 roku Kutek wystąpił o wizę wielokrotną, a konsulat odmówił mu jej udzielenia, to wówczas korespondencyjnie lub telefonicznie załatwił tę sprawę w Warszawie. W rezultacie MSZ przysłało polecenie wydania Kutkowi takiej wizy. Taka sytuacja utrudniała londyńskiej rezydenturze działalność operacyjną wobec dyrektora Fregaty, który bez ograniczeń mógł przyjeżdżać do kraju. Londyńska rezydentura wywiadu żaliła się również na lekceważący stosunek Fregaty do Konsulatu Generalnego nad Tamizą. Podejrzewano nawet, że Kutek pracował dla kontrwywiadu brytyjskiego.

W styczniu 1959 roku, podczas pobytu Kutka w Warszawie, funkcjonariusz wywiadu przeprowadził z nim rozmowę informacyjną na temat sytuacji na emigracji. Dyrektor Fregaty uprzejmie przyjął pracownika MSW i wyraził gotowość przekazania swej opinii. W następnych miesiącach odbyły się jeszcze dwie rozmowy (ostatnia w sierpniu 1960 roku). W ocenie wywiadu nie wniosły one jednak nic konkretnego.

${ }^{42}$ Tamże. 29-30, Notatka z 16 września 1958; AIPN, 01136/102, Notatka z 12 września 1963 dot. A. Kutka. 
Informacje przekazane przez Kutka nie wychodziły poza londyńskie plotki i wiadomości gazetowe.

Dyrektorowi Fregaty tajne służby wystawiały zdecydowanie negatywną opinię. W Notatce z 1963 roku pisano:

Na terenie Londynu Kutek jest powszechnie znany i nielubiany. Ma opinię człowieka nieuczciwego, chełpliwego i zarozumiałego. Uważa, że wszyscy zazdroszczą mu majątku, inicjatywy oraz bardzo szerokich i wpływowych znajomości w kraju. Tą ostatnią opinię Kutek umiejętnie podsyca i rozbudowuje. Jest ambitny, żądny pieniędzy, powodzenia i uznania. Chce, aby się z nim liczono ${ }^{44}$.

We wnioskach dla kierownictwa wywiadu podkreślono: „Nie możemy tolerować dotychczasowych stosunków Fregata-Orbis i roli Kutka”. Planowano przystąpić do „aktywnego rozpracowania" emigracyjnego biznesmena. W porozumieniu z Departamentem II (kontrwywiad) i III (społeczno-polityczny) miano ustalić i sprawdzić wszystkie krajowe kontakty Kutka oraz spowodować rozwiązanie umów z Fregatą przez Orbis i Bank PKO. W oparciu o uzyskane dane zamierzano opracować plan rozmowy z dyrektorem Fregaty w celu jego werbunku lub zdemaskowania go jako „człowieka wrogiego i dwulicowego",45.

Już kilka miesięcy wcześniej, 19 lutego 1963 roku, podporucznik Tadeusz Osmulski, rozpatrzywszy materiały dotyczące Kutka, przygotował formalne postanowienie o założeniu sprawy ewidencyjno-obserwacyjnej o kryptonimie „Kuter”46.

Z planów zwerbowania Kutka nic jednak nie wyszło. Ze względu na jego „nieuczciwą postawę" podczas sondażowych rozmów na terenie kraju wywiad zerwał $\mathrm{z}$ nim kontakt ${ }^{47}$. Ostatecznie major Stefan Serbin 23 listopada 1966 roku przygotował postanowienie o zaniechaniu dalszego prowadzenia sprawy „Kuter” i przekazaniu materiałów do archiwum Departamentu I. W uzasadnieniu oficer wywiadu stwierdził, że Kutek to ,wróg PRL”:

Jego kontakty z naszymi placówkami — dodał — wypływają z potrzeb firmy [Fregata].

Zainteresowanie «Kutra» koncentruje się w kraju i tu rozbudowuje [on] swoje kontakty ${ }^{48}$.

Ponieważ rozpracowaniem emigracyjnego biznesmena zajmował się równocześnie kontrwywiad major, Serbin nie widział potrzeby dublowania sprawy ${ }^{49}$.

W opisanych przypadkach działania wywiadu cywilnego PRL podejmowane wobec emigracyjnych biznesmenów nie przyniosły właściwie żadnych rezultatów. Komunistyczne tajne służby nie mogły się pochwalić sukcesem na tym odcinku. Nieco inaczej wyglądała pod tym względem sytuacja w kontaktach z Polonią amerykańską w latach siedemdziesiątych i osiemdziesiątych XX wieku, ale to już inna historia ${ }^{50}$.

\footnotetext{
${ }^{44}$ AIPN, 01136/102, Notatka z 12 września 1963 dot. A. Kutka.

${ }^{45}$ Tamże.

${ }^{46}$ Tamże, Postanowienie z 19 lutego 1963 o założeniu sprawy ewidencyjno-obserwacyjnej kryptonim „Kuter”.

${ }^{47}$ Tamże, Notatka z 10 czerwca 1965 dot. T. Kutka.

48 Tamże, Postanowienie z 23 listopada 1966 o zakończeniu i przekazaniu sprawy kryptonim „Kuter” do archiwum Departamentu I.

${ }^{49}$ Tamże.

${ }^{50} \mathrm{O}$ kontaktach gospodarczych z Polonią amerykańską wspomina S. Cenckiewicz, Oczami bezpieki. Szkice i materiały z dziejów aparatu bezpieczeństwa PRL, Łomianki 2014 [wyd. 2], s. 207, 211-213.
} 


\section{LITERATURA}

Archiwum Instytutu Pamięci Narodowej, 01237/144;

S. Cenckiewicz, Oczami bezpieki. Szkice i materiaty z dziejów aparatu bezpieczeństwa PRL, Łomianki 2014;

B. Czaykowski, B. Sulik, Polacy w W. Brytanii, Paryż 1961;

R. Habielski, Życie społeczne i kulturalne emigracji, Warszawa 1999;

S. Jóźwiak, Przedmowa, [w:] Polski informator przemystowo-handlowy, oprac. S. Konieczko, Londyn 1958;

T. Kutek, Syzyfowe prace: Polskie Linie Lotnicze „LOT” i moich czterdzieści kilka lat niespetnionych dążé, Chicago 1999;

S. S. Nicieja, Z Kijowa na Piccadilly. Wokół biografii Tadeusza Zabłockiego-Gwasza, Opole 1994;

T. Radzik, Z dziejów społeczności polskiej w Wielkiej Brytanii po drugiej wojnie światowej (1945-1990), Lublin 1991;

A. Robiński, Przedmowa, [w:] Polski informator przemysłowo-handlowy, oprac. A. Dzieduszycki, Londyn 1963;

B. Sikorski, Gospodarcze aspekty emigracji polskiej we Francji i Wielkiej Brytanii, Problemy Polonii Zagranicznej 1966/1967 t. 5, s. 194-199;

K. Sword, Identity in flux. The Polish community in Britain, London 1996;

K. Sword, N. Davies, J. Ciechanowski, The formation of the Polish community in Great Britain 1939-1950, London 1989;

Wspótpraca gospodarcza Polski z Polonia brytyjska, oprac. W. Kudła, Warszawa 1980;

J. Zubrzycki, Socjologia polskiej emigracji, Kultura 1954 nr 7/8 (81-82), s. 118-133 i nr 9 (83), s. 77-93;

J. Zubrzycki, Polish immigrants in Britain: a study of adjustment, The Hague 1956.

\section{TAZAB, HASKOBA, FREGATA: THE BUSINESS OF IMMIGRANTS IN GREAT BRITAIN AND THE POLISH PEOPLE'S REPUBLIC (PRL) INTELLIGENCE (THE 50'S AND 60'S OF THE 20 ${ }^{\text {TH }}$ CENTURY)}

During the first half of the 1960's Polish immigrants in Great Britain owned approx. 3.5 thousand ventures. The immigration business structure was dominated by small companies, set on Polish customers, employing mainly Poles, the fastest developing branch were shipping companies. The direct contacts between the immigrants and the country contributed to creating Polish travel agencies. The PRL intelligence was trying to recruit the businessmen immigrants to become secret collaborators.

Keywords: business during immigration, Tazab, Haskoba, Fregata, PRL intelligence. 